\title{
ALPHONSE KARR, Sous les tilleuls
}

\section{Lise Sabourin}

\section{(2) OpenEdition \\ Journals}

Édition électronique

URL : https://journals.openedition.org/studifrancesi/32018

DOI : 10.4000/studifrancesi.32018

ISSN : 2427-5856

\section{Éditeur}

Rosenberg \& Sellier

Édition imprimée

Date de publication : 1 août 2020

Pagination : 424

ISSN : 0039-2944

\section{Référence électronique}

Lise Sabourin, " alPHONSE KARR, Sous les tilleuls », Studi Francesi [En ligne], 191 (LXIV | II) | 2020, mis en ligne le 01 septembre 2020, consulté le 18 septembre 2021. URL : http://journals.openedition.org/ studifrancesi/32018; DOI : https://doi.org/10.4000/studifrancesi.32018

Ce document a été généré automatiquement le 18 septembre 2021.

\section{(c)}

Studi Francesi è distribuita con Licenza Creative Commons Attribuzione - Non commerciale - Non opere derivate 4.0 Internazionale. 


\title{
ALPHONSE KARR, Sous les tilleuls
}

\author{
Lise Sabourin
}

\section{RÉFÉRENCE}

ALPHONSE KARR, Sous les tilleuls, texte établi et présenté par A. Lascar, Paris, Société des texte français modernes, 2019, $668 \mathrm{pp}$.

1 Pour la plupart, nous avons entendu parler du roman Sous les tilleuls du célèbre journaliste des «Guêpes», mais peu ont eu jusqu'à présent le plaisir de le manipuler en livre: c'est ce que nous permet son édition présentée (pp.7-64) et annotée par Alex Lascar à la Société des textes français modernes.

Ce roman de couleur germanique, dont les courts chapitres sont majoritairement constitués de lettres entre les personnages, mais aussi parfois d'intrusions directes de l'auteur dans sa narration, est représentatif de l'excentricité des années 1830, même si Karr le pratique à sa façon, mesurée, se permettant des excursus déconcertants, des hiatus parfois entre événements et de petites touches sataniques ou macabres, sans perdre pour autant le sens de l'humour et de la raillerie. Son traitement des épigraphes, floues dans leur origine pour un bon nombre, est typique de cette volonté ironique d'entretenir l'incertitude sur les relations entre ses héros, surtout à propos de l'idéaliste finalement redoutable Stephen. L'ajout écrit en 1838, inséré en 1845, des chapitres CVII à CXI, sur le récit de Mme de Rechteren, finit de donner une tonalité $\mathrm{XVIII}^{\mathrm{e}}$ quasi diderotienne à ces scènes de la vie privée bourgeoise. Et la lettre à Madame***, née Camille, invite à chercher la projection autobiographique dans ce récit apparemment détaché.

3 Les annexes (pp. 521-641) fournissent les vignettes conçues par les frères Johannot pour l'édition de 1832, des jugements parus dans les journaux sur le roman de sa parution à 1850, avant bibliographie et index des noms et lieux. 